hensive studies have been made of the distribution of various species of the plankton fauna in the Southern Ocean and in the Benguela Current. An interesting feature is the tendency for populations of different species of zooplankton to be segregated in concentric circumpolar zones. A technique for obtaining underwater photographs of squid has been developed and used successfully at depths of $300-1,000 \mathrm{~m}$.

Work has been continued on the distribution and life cycles of whales, a knowledge of which is required in formulating international regulations. An investigation is being made of two alternative methods of age determination in baleen whales : by the laminations in the ear plugs and from the accumulated corpora albicantia in the ovaries. A comprehengive paper has been published on the biology of sperm whales, and a study of ambergris is in progress. Work is also being done on the geographical distribution of the various species of whale and their movements between one ocean area and another.

R.R.S. Discovery $I I$ was kept in full commission throughout the year, although for three months she was on hire to the Admiralty and so not employed on the Institute's research programme. For six weeks in July-August 1956 the ship was lent to the Department of Geodesy and Geophysics of the University of Cambridge, for a cruise to the Mid-Atlantic Ridge, which included seismic studies and messurements of heat flow through the sea bed.

The Institute has continued to be directed by Dr. G. E. R. Deacon with Dr. N. A. Mackintosh as deputy director. Its total staff is about eighty (excluding the officers and crew of Discovery $I I$ ), of whom thirty-six are in the scientific and experimental officer grades. In addition, seven visiting scientists from overseas were working in the Institute during the year. The expenditure on the year's work amounted to $£ 193,000$, of which $£ 78,000$ was for running Discovery $I I$. The main source of income was $£ 110,000$ in grants from the United Kingdom Government. Commonwealth Governments contributed $£ 9,000$. The Treasury has decided to increase its grants to $\$ 175,000$ per annum for the next five years and this should go a long way towards ensuring the further development of the Institute's research programme.

K. F. BOWDEN

\title{
OPENCAST MINING
}

$\mathrm{T}$ THE Opencast Coal Bill, which had an unopposed second reading in the House of Commons on January 22, is a complicated Bill which replaces the powers at present exercised under Defence Regula. tions by a system of planning control, acquisition and compensation incorporating some of the main points made in the Franks report. It provides that no opencast operations can take place without the permission of the Minister, who will, in his consent, insert conditions ensuring that damage is reduced to the minimum, and, when agricultural land is affected, that the land be restored to a reasonably fit state for agriculture.

It is intended to proceed wherever possible by agreement, and the compulsory rights order when used will give the Coal Board the right for a maximum of ten years to use the land for opencast mining. In moving the second reading, the PaymasterGeneral, Mr. R. Maudling, said there would be a continuing need for opencast cosl for a considerable period : about 160 million tons of coal had been produced by this method from 109,000 acres, $13 \cdot 5$ million tons of this in 1957, and the need was generally but reluctantly accepted by the House; though Mr. Maudling, and Mr. A. Robens for the Opposition, alike recognized the damage done to amenity and agriculture and our duty to hand on the land in a better and not a worse condition.

While Mr. G. Nabarro condemned opencast mining generally but supported the Bill, Mr. M. Philips Price and Mr. R. Speir pressed more specifically for safeguards and greater attention to amenity both in mining and in restoring the land. In replying on the debate, the Parliamentary Secretary to the Ministry of Power, Sir Ian Horobin, urged that, given the need for opencast mining, while the provisions of the Bill were not perfect, they were probably the best we could make. The vital question of amenity had not been overlooked and would be permanently in the minds of the Ministers who had to administer the Act. Improvements could possibly be made during the Committee stage and compensation would no longer be arbitrary.

\section{ANIMAL HEALTH IN GREAT BRITAIN}

\begin{abstract}
NYONE interested in the health of domesticated A animals and in their transit to and from Great Britain should read the "Report on the Animal Health Services in Great Britain 1956" (H.M.S.O., London, 6s. net), which includes a report on proceedings under the Diseases of Animals Act, 1950. The outstanding features of the report are, on the debit side, the high incidence, during 1956, of foot and mouth disease and anthrex, and the increase of fowl pest ; but these liabilities were offset by the steady progress of the Ministry of Agriculture's scheme for the eradication of tuberculosis from oattle in Great Britain, by the demonstration by the Ministry's veterinarians in the Isle of Wight that warble fly
\end{abstract}

disease can be substantially reduced by co-operation between the veterinarian and the farmer, and by the evidence provided in the report of the very wide range of research that is being devoted to the diserses of domesticated animals.

The year 1956 was the worst year for foot and mouth disease since the widespread outbreaks of 1951 and 1952 . In 1956 there were 162 outbreaks, but these were confined to England and Wales. Of the 162 outbreaks, thirty-two, which had no known connexion with other outbreaks, were attributed either to swill or to imported meat, bones or meat wrappers, and it was concluded that the disease came from the Continent. It was necessary to slaughter 10,547 